Louisiana State University

LSU Digital Commons

$11-9-2006$

\title{
Electrophile-induced ether transfer: A new approach to polyketide structural units
}

Kai Liu

University of Notre Dame

Richard E. Taylor

University of Notre Dame

Rendy Kartika

University of Notre Dame

Follow this and additional works at: https://digitalcommons.Isu.edu/chemistry_pubs

\section{Recommended Citation}

Liu, K., Taylor, R., \& Kartika, R. (2006). Electrophile-induced ether transfer: A new approach to polyketide structural units. Organic Letters, 8 (23), 5393-5395. https://doi.org/10.1021/ol0623318

This Article is brought to you for free and open access by the Department of Chemistry at LSU Digital Commons. It has been accepted for inclusion in Faculty Publications by an authorized administrator of LSU Digital Commons.

For more information, please contact ir@lsu.edu. 


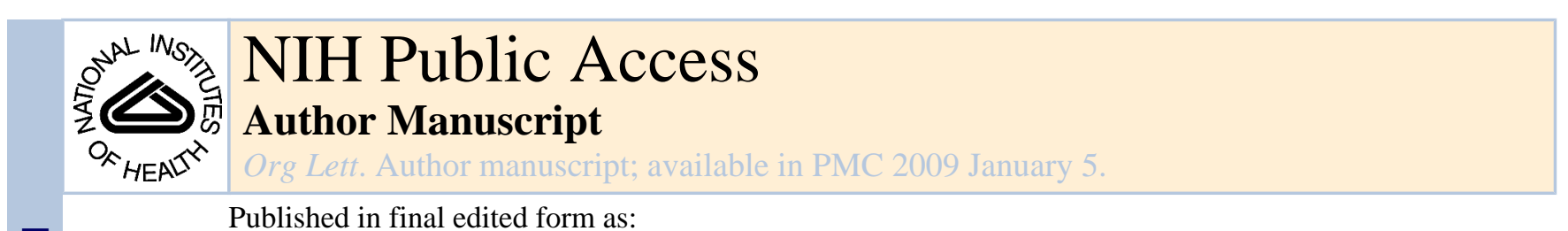

Published in final edited form as:

Org Lett. 2006 November 9; 8(23): 5393-5395. doi:10.1021/ol0623318.

\section{Electrophile Induced Ether Transfer: A New Approach to Polyketide Structural Units}

Kai Liu, Richard E. Taylor, and Rendy Kartika Department of Chemistry and Biochemistry and the Walther Cancer Research Center, University of Notre Dame, 251 Nieuwland Science Hall, Notre Dame, IN 46556-5670

Abstract

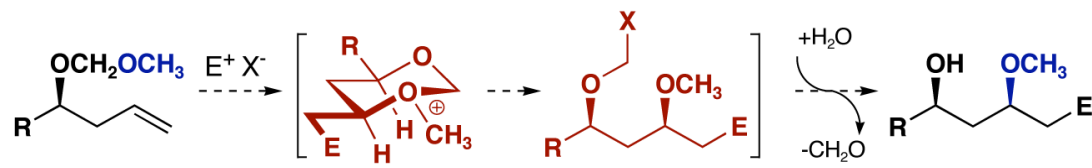

A strategically novel approach to the formation of syn-1,3-diol mono- and diethers through electrophilic activation of homoallylic alkoxymethyl ethers has been developed. The resulting polyketide-like synthetic fragments are generated in good yield and with excellent stereocontrol. A chair-like transition state is proposed to account for the high stereoselectivity. Varying the conditions of reaction workup results in the efficient generation of mono- and diether containing structural units common to polyketide natural products.

Polyketides represent an important class of natural products due to their diverse biological activity. Numerous polyketide natural products contain methyl ether functionality generated by either methoxymalonyl extender units or a selective $O$-methyl transferase associated with the PKS gene cluster. Peloruside A, a representative example that has received significant, recent, synthetic interest, ${ }^{1,2}$ contains three such methyl ethers. Unfortunately, current synthetic methods for ether generation lack the selectivity of evolved proteins. Thus, discrete steps for generating a hydroxyl stereogenic center and subsequent methylation are typically bracketed by additional protecting group manipulation steps.

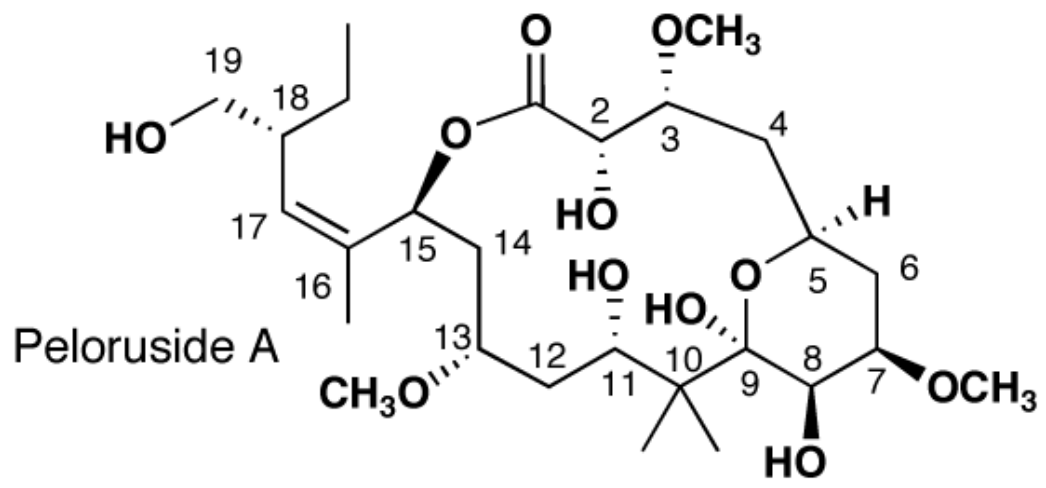

taylor.61@nd.edu.

Supporting Information Available

Full experimental and characterization data for all new compounds. This material is available free of Charge via the Internet at http://pubs.acs.org. 
A practical solution to this problem would utilize methanol as a coupling partner, but classic intermolecular iodoetherifications are unlikely to be stereo- and/or regioselective. However, the repeating pattern of 1,3-oxygenation, common to polyketides, offers the opportunity to exploit intramolecular delivery. Herein, we report a practical solution to the methyl ether problem associated with the synthesis of many polyketide natural products. Moreover, the new chemistry presented offers additional opportunities for the development of strategically novel approaches to the synthesis of structural units common to polyketide natural products.

The general approach is outlined in Scheme 1. A readily available homoallylic alcohol, protected as a methoxymethyl ether (MOM), will be subjected to electrophilic activation conditions, $\mathrm{E}^{+}$(e.g.; $\mathrm{I}_{2}, \mathrm{IBr}, \mathrm{ICl}, \mathrm{NIS}, \mathrm{PhSeCl}$, etc.). Based on related cyclizations of homoallylic carbonates, ${ }^{3}$ we expected formation of intermediate oxonium ion $\mathbf{2 a}$, through a chair-like transition state, leading to halomethyl ether $\mathbf{2 b}$. Hydrolysis would then provide a syn-1,3-diol monoether 3 . In contrast to current technology, stereochemistry would be generated simultaneous to the ether functionality. ${ }^{4,5}$

The results of the initial exploration of the ether-transfer concept using a variety of electrophilic conditions are listed in Table 1. Methoxymethyl protected homoallylic alcohol $\mathbf{1}$ was prepared in two steps in racemic form from commercially available materials. Toluene was shown to be the most suitable solvent. The choice of activation reagent was also critical in minimizing the formation of an alternative cyclization product, tetrahydrofuran 4 . Entry 8 demonstrated that methoxy transfer could be successfully accomplished in both high yield and high diastereoselectivity. 6

Presumably, related ethers would transfer efficiently as long as steric or electronic differences compared to the methyl substrate were insignificant. In fact, the benzyloxymethyl substrate 5 , readily prepared from commercially available $\mathrm{BOMCl}$, underwent efficient benzyl ether transfer, Scheme $2 .^{6 b, c}$ This process significantly expands the scope of the reaction since, in contrast to methyl ethers, benzyl groups can be easily removed by hydrogenolysis. Thus, the ether transfer method provides access to orthogonally protected syn-1,3-diol units.

Surprisingly, no products related to tetrahydrofuran $\mathbf{4}$ were observed with the corresponding benzyloxymethyl substrate 5 . However, under $\mathrm{IBr} / \mathrm{CH}_{2} \mathrm{Cl}_{2}$ conditions competitive benzyl cleavage was observed and acetal 7 was isolated as the major product. ${ }^{7}$ Activation with $\mathrm{ICl}$ in toluene provided exclusively the ether transfer product $\mathbf{6}$.

The intermediacy of chloromethyl ether $\mathbf{2 b}$ was supported by NMR observation in toluene$d_{8}$ (see supporting information). Thus, we speculated that a methanolic workup would regenerate the methoxylmethyl group and provide access to orthogonally protected diethers. Successful demonstration of this idea as well as the overall scope of the ether transfer is highlighted in Table 2. Reaction workup with either MeOTMS or basic methanol solutions provided diethers in good yield and excellent diastereoselectivity, entries 1 and 2. Moreover, benzyl alcohol workup generated a BOM-ether and provided 13. Propionate substrates 16 and 18 demonstrated a strong preference for 1,3-syn products regardless of the stereochemistry of allylic substitution (entries 5 and 6). For evaluation of the scope of this chemistry, entry 7 was an important test. Appropriate protecting group selection ${ }^{8}$ enabled exclusive ether transfer and alternative cyclization events were not observed. These results augur well for application of this methodology to the synthesis of more complicated polyketide-like structures.

The in situ generated chloromethyl ether $\mathbf{2 b}$ is a versatile intermediate with the ability to react with variety of nucleophiles and provide unique structures applicable to natural product synthesis. An additional example, complementary to the ether transfer, is shown in Scheme 3. Electrophilic activation followed by a reductive workup provided access to methyl ethers 
through selective hydride addition. Coupled with a lithium borohydride quench, the MOMprotected substrate $\mathbf{1}$ provided the bis-methyl ether $\mathbf{2 4}$ in $91 \%$ yield.

The reaction shown in Scheme 3 is ideally suited for application to the synthesis of the isotactic polymethoxydiene class of marine polyketides. ${ }^{9}$ Similarly, the BOM-protected substrate 5 provided the orthogonally protected diether substrate $\mathbf{2 5}$, a stereocomplementary fragment to diether 9.

Methods for the asymmetric synthesis of polyketide structural units have evolved such that even gram-scale syntheses of complex natural products are obtainable given proper rationale. ${ }^{10}$ We have developed a fundamentally new tactic capable of significantly simplifying the creation of functionality common to polyketide natural products by controlling the generation of a stereogenic center simultaneous with ether incorporation. Moreover, the demonstrated ability to trap the intermediate with a variety of nucleophiles offers additional opportunities for synthetic creativity. Application of these methods to our secondgeneration synthesis of peloruside $\mathrm{A}$ as well as other natural products is currently underway in our laboratories and will be reported in due course.

\section{Supplementary Material}

Refer to Web version on PubMed Central for supplementary material.

\section{Acknowledgement}

Support provided by the National Institutes of Health through the National Cancer Institute (CA85499) and National Institute of General Medical Science (GM077683) is gratefully acknowledged.

\section{References}

1. (a) Liao X, Wu Y, De Brabander JK. Angew. Chem. Int. Ed 2003;42:1648-1652.For the total syntheses of peloruside A see; (b) Jin M, Taylor RE. Org. Lett 2005;7:1303-1305. [PubMed: 15787492]

2. (a) Paterson I, Di Francesco ME, Kühn T. Org. Lett 2003;5:599. [PubMed: 12583779]For additional synthetic efforts towards peloruside A see; (b) Ghosh AK, Kim J-H. Tetrahedron Lett 2003;44:3967. (c) Taylor RE, Jin M. Org. Lett 2003;5:4959. [PubMed: 14682739] (d) Ghosh AK, Kim J-H. Tetrahedron Lett 2003;44:7659. (e) Gurjar MK, Pedduri Y, Ramana PCV, Puranik VG, Gonnade RG. Tetrahedron Lett 2003;45:387. (f) Liu B, Zhou W-S. Org. Lett 2004;6:71. [PubMed: 14703353] (g) Engers DW, Bassindale MJ, Pagenkopf BL. Org. Lett 2004;6:663. [PubMed: 14986944] (h) Roulland E, Ermolenko MS. Org. Lett 2005;7:2225. [PubMed: 15901175] (i) Owen RM, Roush WR. Org. Lett 2005;7:3941. [PubMed: 16119937] (j) Hoye TR, Ryba TD. J. Am. Chem. Soc 2005;127:8256. [PubMed: 15941238]

3. (a) Bartlett PA, Meadows JD, Brown EG, Morimoto A, Jernstedt KK. J. Org. Chem 1982;47:40134018. (b) Duan JJ-W, Smith AB III. J. Org. Chem 1993;58:3703-3711.

4. (a) Cumpstey I, Chayajarus K, Fairbanks AJ, Redgrave AJ, Seward CMP. Tetrahedron: Asymmetry 2004;15:3207.A related delivery of an ether has been applied to the stereocontrolled synthesis of glycosides; (b) Gauthier DR Jr. Zandi KS, Shea KJ. Tetrahedron 1998;54:2289. This chemistry is in a class of reactions defined by temporary tethers;

5. (a) Molas P, Matheu MI, Castillíon S. Tetrahedron Lett 2004;45:3721.This chemistry is in a class of reactions defined by temporary tethers; (b) Fujioka H, Ohba Y, Hirose H, Murai K, Kita Y. Angew. Chem. Int. Ed 2005;44:734. (c) Kumar VS, Aubele DL, Floreancig PE. Org. Lett 2002;4:2489. [PubMed: 12123358]

6. (a) Hoffman RW, Weidmann U. Chem. Ber 1985;118:3980.The syn stereochemistry was determined by NMR spectroscopic analysis; (b) Rychnovsky SD, Skalitzky DJ. Tetrahedron Lett 1990;31:945. The syn-1,3-relative stereochemistry was determined by hydrogenolysis of the benzyl ether and ${ }^{13} \mathrm{C} \mathrm{NMR}$ spectroscopic analysis of the corresponding acetonide.Evans DA, Rieger DL, Gage JR. Tetrahedron Lett 1990;31:7099.

Org Lett. Author manuscript; available in PMC 2009 January 5. 
7. Rychnovsky SD, Barlett PA. J. Am. Chem. Soc 1981;103:3963.Deprotection of benzyl ethers involved in iodoetherification reactions is well established;

8. Shambayati S, Blake JF, Wierschke SG, Jorgensen WL, Schreiber SL. J. Am. Chem. Soc 1990;112:697.For a discussion of the lowered basicity of silyl ethers relative to alkyl ethers see; 9. Rao MR, Faulkner DJ. J. Nat. Prod 2002;65:1201. [PubMed: 12193033]

10. Mickel SJ. Curr. Opin. Drug Dev 2004;7:869. 


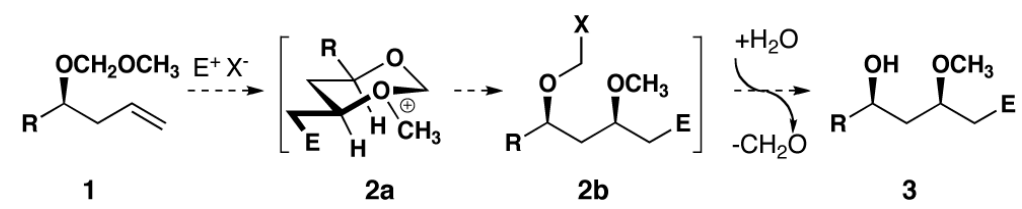

Scheme 1.

Electrophile-Induced Ether Transfer: General Strategy 

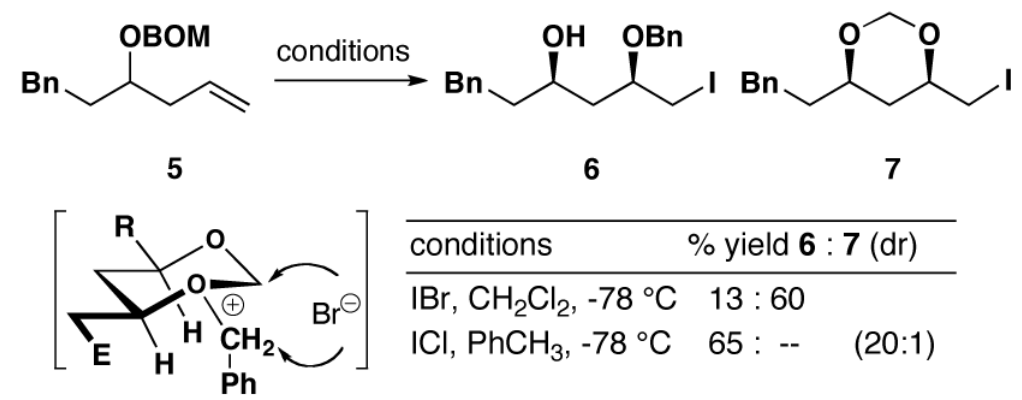

Scheme 2.

Electrophile-Induced BenzylTransfer: Competive Cleavage 


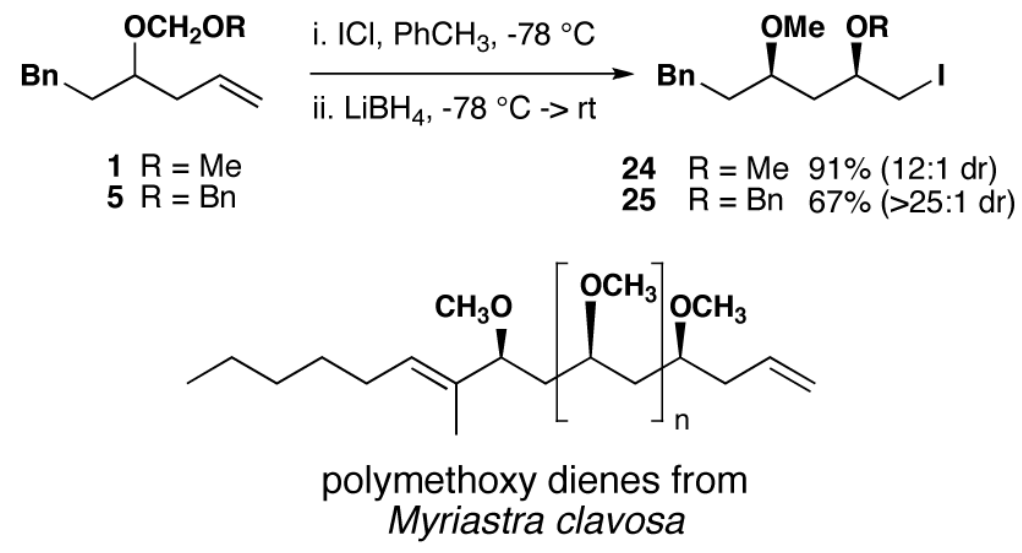

Scheme 3.

Electrophile-Induced Ether Transfer: Reductive Quench 
Table 1

Electrophile-Induced Methoxy Transfer: Initial Exploration

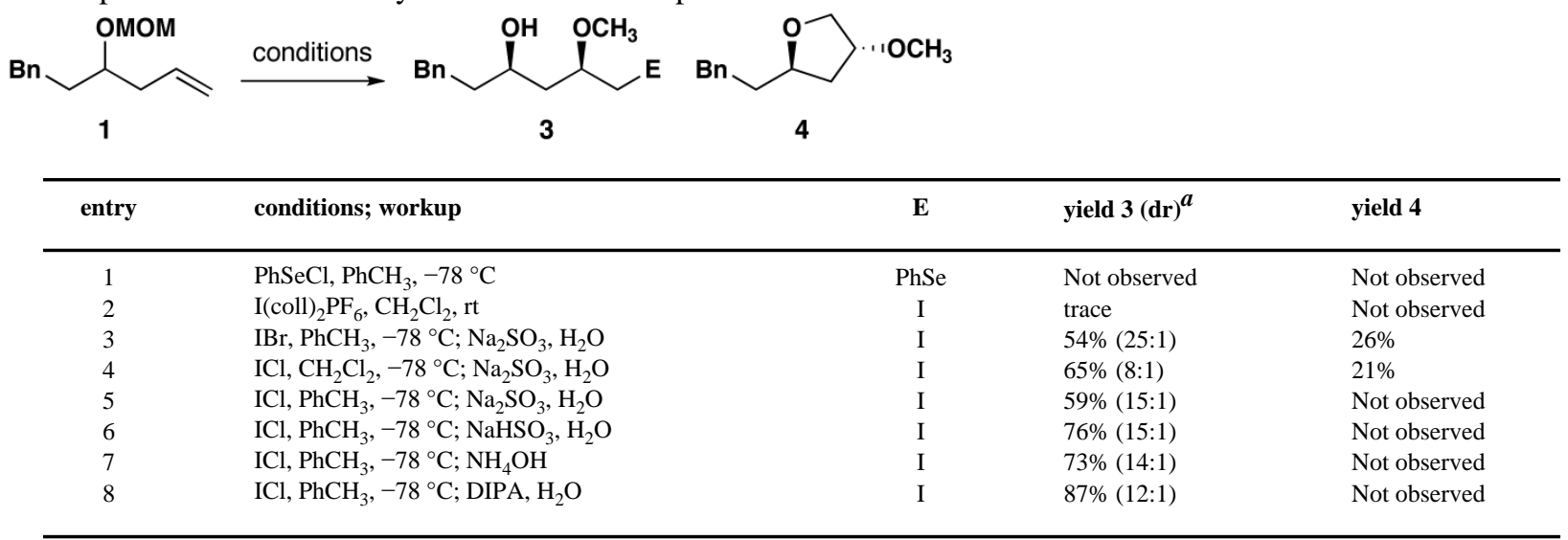

${ }^{a}$ Diastereomeric ratio was determined by ${ }^{1} \mathrm{H}$ and ${ }^{13} \mathrm{C}$ NMR. ${ }^{6 \mathrm{a}}$ 
Table 2

Electrophile-Induced Methoxy Transfer: Reaction Scope

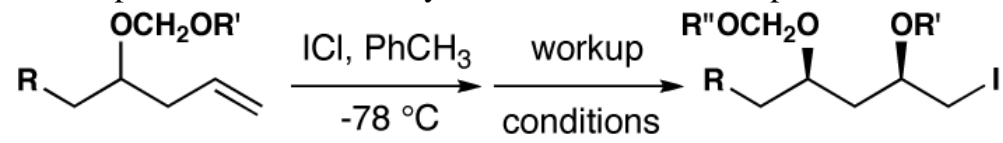

entry

$a_{\mathrm{TMSOCH}_{3}}$

${ }^{b} \mathrm{CH}_{3} \mathrm{OH}, i \operatorname{Pr} 2 \mathrm{NEt}$

${ }^{c} \mathrm{BnOH}, i \mathrm{Pr} 2 \mathrm{NEt}$

${ }^{d}{ }_{\mathrm{AcOH}, i \operatorname{Pr} 2 \mathrm{NEt} ;-78^{\circ} \mathrm{C}->\mathrm{rt}}$ 